\title{
Schreiteriana klagesi sp.n. (Lepidoptera: Cossidae, Zeuzerinae) from Brazil
}

\section{Schreiteriana klagesi sp.n. (Lepidoptera: Cossidae, Zeuzerinae) из Бразилии}

\author{
R.V. Yakovlev ${ }^{1,2,3}$, A.E. Naydenovi ${ }^{1}$ F.C. Penco ${ }^{4}$ \\ Р.В. Яковлев ${ }^{1,2,3}$, А.Е. Найденов ${ }^{1}$, Ф.Ц. Пенко ${ }^{4}$
}

\footnotetext{
${ }^{1}$ Altai State University, pr. Lenina 61, Barnaul, 656049, Russia.

2 Tomsk State University, Laboratory of Biodiversity and Ecology, Lenin pr. 36, 634050 Tomsk, Russia. E-mail: yakovlev_asu@mail.ru

${ }^{3}$ PaleoData Lab., Institute of Archaeology and Ethnography SB RAS, Novosibirsk, Russia.

${ }^{4}$ Fundación de Historia Natural "Félix de Azara", Departamento de Ciencias Naturales y Antropología, Universidad Maimónides, Hidalgo 775 piso 7 (1405BDB) Ciudad Autónoma de Buenos Aires, Argentina. E-mail: fernando_penco@hotmail.com

${ }^{1}$ Алтайский государственный университет, пр. Ленина 61, Барнаул 656049, Россия.

2 Томский государственный университет, пр. Ленина 36, Томск 634050, Россия.

${ }^{3}$ PaleoData Lab., Институт археологии и этнографии CO PAH, Новосибирск, Россия.
}

KEY WORDS: entomology, biodiversity, Carpenter moths, Zeuzerinae, fauna, Neotropical Region.

КЛЮЧЕВЫЕ СЛОВА: энтомология, биоразнообразие, древоточцы, фауна, Неотропический регион.

ABSTRACT. The article describes a new species, Schreiteriana klagesi Yakovlev, Naydenov et Penco, sp.n. from Fonte Boa, (Amazonas, Brazil), which is clearly distinguished from all the known species in its light-brown color of the wings, contrasting dark-brown veins and the wavy abdominal edge of the valve.

РЕЗЮМЕ. В статье описан новый вид Schreiteriana klagesi Yakovlev, Naydenov et Penco, sp.n. из ФонтеБоа, (штат Амазонас, Бразилия), хорошо отличающийся от известных видов светло-коричневой окраской крыльев, контрастными темно-коричневыми жилками и волнистым абдоминальным краем вальвы.

\section{Introduction}

The genus Schreiteriana Fletcher et Nye, 1982 (Lepidoptera: Cossidae, Zeuzerinae) (Type species (by monotypy) Schreiteria pectinicornis Dyar, 1937), according to our data, includes six species distributed in South America (Argentina, Colombia, Paraguay and Peru) [Penco et al., 2016; Yakovlev et al., 2017]. They are small moths (wingspan of $22-35 \mathrm{~mm}$ ), which can be attracted to light. Their biology is unknown.

Examining the Neotropical Cossidae specimens, deposited in the Natural History Museum (London, U.K.) we discovered a new species of the genus Schreiteriana, its description is given below.

\section{Material and methods}

Images of imago were taken by the camera of Canon EOS 70D and illuminated in Lightbox. The male genitalia slides [Lafontaine, 2004] were examined with an Olympus SZX16 microscope. The images were taken with the Olympus SZX16 camera. The genitalia and imago images were processed using Corel Draw software.

\section{Description of new species}

$$
\begin{gathered}
\text { Schreiteriana klagesi } \\
\text { Yakovlev, Naydenov et Penco, sp.n. } \\
\text { Figs 1-4. }
\end{gathered}
$$

MATERIAL. Holotype, $0^{\prime}$, Fonte Boa [2³0 $50^{\prime \prime} \mathrm{S} / 66^{\circ} 05^{\prime} 45^{\prime \prime}$ W], Amazonas, [Brazil] July 1906. (S. M. Klages) (Natural History Museum, London, individual number: NHMUK: 012832492, slide number NHMUK: 010315523); $9 \mathrm{O}^{7} \sigma^{7}$, paratypes, Fonte Boa, Amazonas, July 1906. (S. M. Klages) (Natural History Museum).

DESCRIPTION. Length of fore wing of the holotype 14 $\mathrm{mm}$ (paratypes 13-14 $\mathrm{mm}$ ). Head, thorax and abdomen lightbrown. Antenna bipectinate in proximal half, in distal half crest processes very short, hardly noticeable. Crest processes is proximal half 2-3 times longer than antenna rod diameter. Fore wing light-brown, with small brown stroke in root area (at costal edge) and at top of discal cell, veins contrasting, brown, border brown, fringe brown, unicolorous. Hind wing light-brown without pattern, veins contrasting, brown, border brown, fringe brown, unicolorous.

How to cite this article: Yakovlev R.V., Naydenov A.E., Penco F.C. 2021. Schreiteriana klagesi sp.n. (Lepidoptera: Cossidae, Zeuzerinae) from Brazil// Russian Entomol. J. Vol.30. No.3. P.336-338. doi: 10.15298/ rusentj.30.3.12 

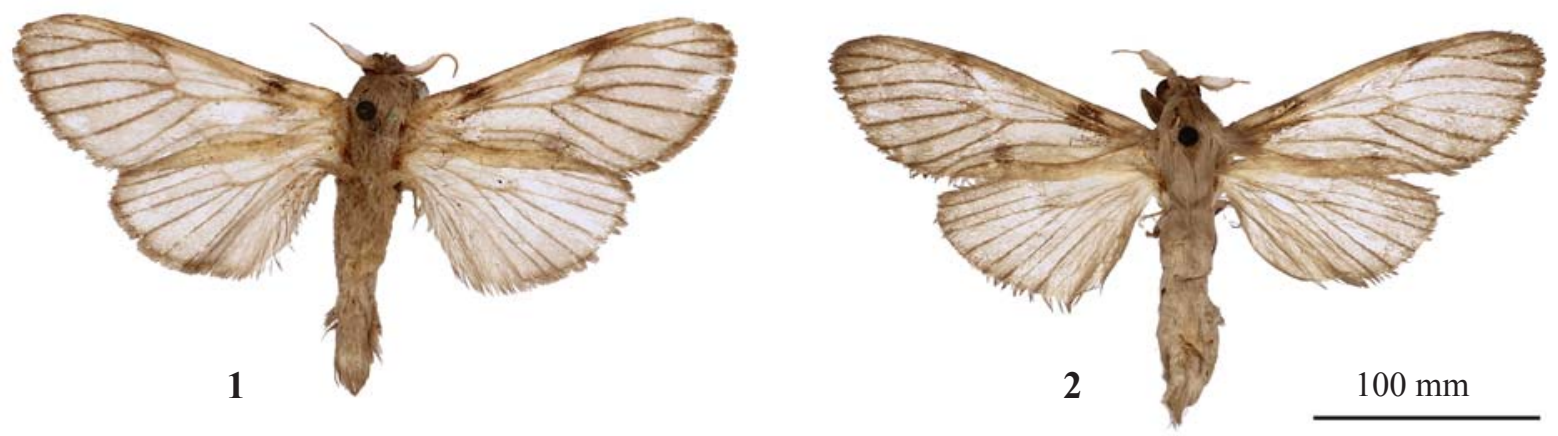

Figs 1-2. Schreiteriana klagesi Yakovlev, Naydenov et Penco, sp.n., adult specimens, males: 1 - holotype; 2 - paratype. Рис. 1-2. Schreiteriana klagesi Yakovlev, Naydenov et Penco, sp.n., имаго, самцы: 1 - голотип; 2 - паратип.

Male genitalia (Slides NHMUK: 010315523 and 010315524). Uncus long, with triangle base, pin-likely narrowing in medium third, apex spear-pointed; gnathos arms ribbon-like, relatively wide, smoothly narrowing from base to apex; gnathos absent; valve gradually narrowing from base to apex, relatively narrow, apex semicircular, costal edge almost smooth, abdominal edge ( $2 / 3$ of its proximal part) wavy, with semicircular notches; juxta robust, semicircular, with long wide ribbon-like lateral processes; saccus semicircular, massive; phallus thick, of equal thickness throughout its length, slightly curved in medium third, with spirally curved big lamellar cornutus and a large zone of scabination in basal portions of vesica.

DIAGNOSIS. The new species differs clearly from all the known species of the genus in the series of characters: the light-brown color of the wings, the contrasting dark-brown veins and the wavy abdominal edge of the valve.

ETYMOLOGY. The new species is named after the collector of the type series, Samuel M. Klages (1875-1957), a well-known collector of South American birds and insects [Kirwan et al. 2015].

DISCUSSION. Schreiteriana klagesi Yakovlev, Naydenov et Penco, sp. nov. was found in western Brazil (the province Amazonas), from where we previously described a new genus, Klagesiana Yakovlev, Naydenov et Penco, 2020 [Yakovlev et al., 2020]. According to Morrone [2014], this locality is on the border of two biogeographical dominions Boreal Brazilian (Imerí Province) and South Brazilian (Madeira Province). Both regions are characterized by a significant level of endemism in various groups of animals. The study of the specimens collected on the borders of biogeographical dominions, are of great importance for the further research of the borders of the biogeographical regions.

Acknowledgments. The author is grateful to Anna Ustjuzhanina (Tomsk, Russia) for the help in translation of the paper. We thank also Geoff Martin, Alessandro Giusti (London, Great Britain), and the Natural History Museum Council of Trustees for the permission to publish the images of specimens deposited in the museum. We also express our gratitude to Xenia Proskuryakova (Moscow, Russia) for the assistance in making the genital preparations.

Figs 3-4. Schreiteriana klagesi Yakovlev, Naydenov et Penco, sp.n., males genitalia: 3 - holotype; $4-$ paratype.

Pис. 3-4. Schreiteriana klagesi Yakovlev, Naydenov et Penco, sp.n., гениталии самцов: 3 - голотип; 4 - паратип.

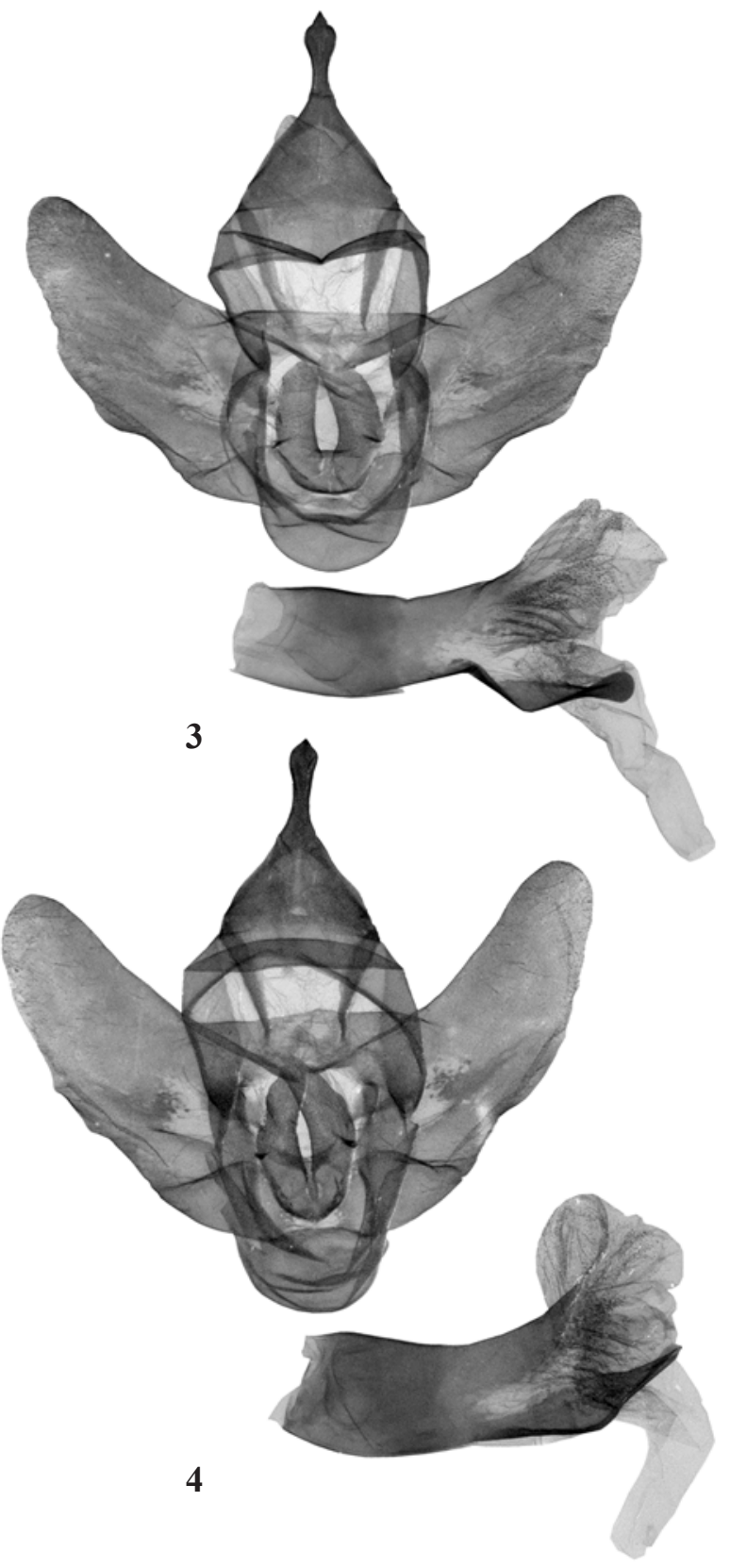


Competing interests. The authors declare no competing interests.

\section{References}

Kirwan G.M., Pacheco J.F., Lees A.C. 2015. First documented record of the Sapphire Quail-Dove Geotrygon saphirina Bonaparte, 1855, in Brazil, an overlooked specimen from the Klages expedition to Amazonia // Revista Brasileira de Ornitologia. Vol.23. No.3. P.354-356.

Lafontaine J.D. 2004. Noctuoidea, Noctuidae (part), Noctuinae (part-Agrotini) // R.W. Hodges (ed.). The Moths of America North of Mexico. Fasc.27.1. The Wedge Entomological Research Foundation, Washington. 385 pp.
Morrone J.J. 2014. Biogeographical regionalisation of the Neotropical region // Zootaxa. Vol.3782. 110 pp. DOI: 10.11646/zootaxa.3782.1.1.

Penco F.P., Yakovlev R.V., Witt Th.J. 2016. Taxonomic notes on the genera Brypoctia Schoorl, 1990 and Schreiteriana Fletcher \& Nye, 1982 (Lepidoptera, Cossidae) // Zootaxa. Vol.4205. No.3. P.297-300. DOI: 10.11646/zootaxa.4205.3.10.

Yakovlev R.V., Naydenov A.E., Penco F.C. 2020. Klagesiana gen. n. - new genus of Carpenter-Moths (Lepidoptera: Cossidae: Zeuzerinae) from Brazil // Ecologica Montenegrina. Vol.27. P.69-73.

Yakovlev R.V., Penco F.C., Witt Th.J. 2017. Five new species of the genus Schreiteriana Fletcher et Nye, 1982 (Lepidoptera: Cossidae) from Peru and Columbia (South America)// Russian Entomological Journal. Vol.26. No.4. P.339-342. 